\title{
Modern Model of Genomic and Other Research Regulations
}

\author{
Nina M. Kolosova* \\ Institute of Legislation and Comparative Law under \\ the Government of the Russian Federation \\ Moscow, Russian Federation
}

Received 01.06.2020, received in revised form 08.06.2020, accepted 15.06.2020

\begin{abstract}
The main goal of this study is to develop a qualitatively new model of public relations' modular regulation, which will overcome stereotypes and shortcomings of legal regulation.

The model of modular regulation is characterised by the convergence of all regulators, the vector direction of impact on social relations and other features. In the conditions of inconsistency of social regulators, the proposed model of modular impact on social relations provides an opportunity for everyone to choose the most effective norm.

Modular regulation should be used only in some areas of social relations, without replacing legal one. Accordingly, the following criteria are recognised for the legality of applying the modular regulation: evidence of the onset of maximum socially dangerous consequences in the case of the application of an erroneous norm of social regulation and a high degree of self-regulation of particular social relations, the presence of specific laws in them.

Given these criteria, it is advisable to use modular regulation in genomic and other research, which is the subject of this article.
\end{abstract}

Keywords: genome, status of researchers, legal regulation, social regulators, modular regulation, the right to make mistakes, gene modification, prohibition of discrimination, genomic testing.

This work was supported by the RFBR grants No. 18-29-14009.

Research area: law.

Citation: Kolosova, N.M. (2020). Modern model of genomic and other research regulations. J. Sib. Fed. Univ. Humanit. Soc. Sci., 13(6), 1020-1027. DOI: 10.17516/1997-1370-0611.

\footnotetext{
(C) Siberian Federal University. All rights reserved

* Corresponding author E-mail address: kolosova-law@mail.ru ORCID: 0000-0002-5401-0277
} 


\section{Introduction}

The relevance of the subject of this study is conditioned by qualitative changes in public and state institutions under the influence of scientific and technological achievements. The objective need for the search for new theories and rethinking of established ones is obvious. Lawyers put forward modern ideas in different directions, including the issue of legal regulators of public relations in the context of digitalisation and new technologies. The legal literature has already addressed the possibility to change the model of social regulation and the place of law in this model in the future ${ }^{1}$.

Along with that, currently legal experts have not proposed the qualitatively new modern model of public relations' regulation. As a rule, the maximum efficiency of legal regulation of public relations is recognised. However, practice often refutes this concept. There are different points of view even in a long-standing discussion about the relationship between law and morality. Some legal experts insist on their coincidence mainly in the context of a positivist understanding of law (Kravets I.A.). Others note the existence of a moral crisis in law (Khabrieva T.Ya.). The problem concerning the legitimacy of the application of moral norms that do not coincide with legal ones remains unresolved.

\section{Theoretical framework}

Without denying the significant regulatory potential of the legislation, we should note the tendency to include not only legal, but also other social and sometimes technical norms in it. This kind of convergence of regulators sometimes creates difficulties in the process of law enforcement. It is noteworthy that the practice of governing the state in emergency conditions, in particular, the coronavirus pandemic, has shown the inefficiency of many existing legal regulators, which had to be adjusted promptly. For example, those include the procedure for drawing up a document on temporary disability, measures of legal liability, restriction of the rights of everyone and more. However,

\footnotetext{
See: Khabrieva T.Ya. (2018). Pravo pered vyzovami tsifrovoi real'nosti [Law facing the challenges of digital reality]. In Zhurnal rossiiskogo prava [Journal of Russian law], 9, 15.
}

there was no conceptual justification for these changes.

Hence the need arises to develop a qualitatively new model for regulating social relations.

\section{Statement of the problem}

In the context of the development of modern technologies, law is not always able to effectively influence certain types of social relations. In addition, the convergence of social norms, sometimes their inconsistency, occasionally makes it difficult to make the best decision.

There are more and more areas of social relations, the regulation of which requires the use of modern approaches to solving problems. For example, big data provides the genetic information with the feature of openness and ubiquity, without prejudice to the admission of third parties to $\mathrm{it}^{2}$. It should be noted that so far, the legislation has not been able to protect the information rights of everyone, balancing private and public interests. Hence the growing need for a search for a model of regulation of particular social relations, that differs from a legal one. Accordingly, in order to overcome the shortcomings of legal regulation, it is advisable to propose to use a modern model, namely, modular effect on public relations.

\section{Methods}

In order to achieve the goal of this study, the author used a deduction method. Thus, first of all, the author studied the structure of the proposed modular regulation and then analysed it in relation to genomic research.

\section{Discussion}

We shall turn to the system of present public relations regulators (individual, normative, and spontaneous) to substantiate the necessity of developing a qualitatively new model of modular regulation of public relations, its structure with its peculiar advantages and disadvantages.

Social norms (morale, customs, traditions, religious rituals, precepts, and prescriptions) are a special element in the process of regulat-

\footnotetext{
Ajunwa I. (2014). Genetic testing meets Big data: Tort and Contract Law issues. In Ohio State Law Journal, 75(6), 1231.
} 
ing public relations, in which the leading role is played by law. Law forms a ramiform and detailed system, characterised by internal unity and intrinsic logical interconnection between separate rules. Moral, traditional, corporate, and religious rights and responsibilities are based on this very law. Also, law, acting as a mandatory state regulator of social relations, significantly differs from other norms of social relations. However, its generally accepted features require thorough reflection against the possibility of their application in the modular regulation process.

Firstly, there is an axiom that law is the only system of norms binding on all members of society. Other norms usually apply to individual social groups. However, this position needs to be adjusted. It is necessary to fulfil not only legal, but also other norms for conducting genomic research.

Secondly, as rule, they think that the norms of law are necessarily fixed in an official form in laws, acts of the Government of the Russian Federation and other. These norms are supposed to have highly formal certainty, precision of fixing rights and obligations. Customs and morality mainly consolidate principles or standards of behaviour. This is a position open to objection, because technical, moral or other norms can be also included in legislation, that means that this association of law with official wording needs to be re-examined.

Thirdly, law is recognised as being established or authorised by the state, and other social norms either emerge spontaneously and exist in the kind of firm beliefs of people, public opinions (morale, customs, traditions), or are developed by public organisations. However, some types of social relationships are regulated by moral, religious norms, that are included in legislation.

Fourthly, law is seen as guaranteed and protected by the state, and all other social norms can only be supported by law if they comply with it. This position is questioned in case of regulation of genomic research, since scientists may use moral regulators to protect the rights of the participants more effectively even if the rights contradict the law. What is in the focus here is the need for regulatory sol- idarity of values, which opts for the most constructive rule of behaviour, while the right to choose is fixed in legislation or ethical code for a specific participant in genomic research.

To overcome the above-mentioned conflicts, it is advisable to propose, develop and apply in the future the so-called modular regulation of public relations, which, unlike the legal regulation, is the achievement of a specific goal by using a set of regulators. The choice of these regulators called modules is subject to certain rules in each specific law enforcement situation.

The following main features of modular regulation of public relations can be identified.

One of them is the already existing convergence of various social regulators, which are sometimes difficult to distinguish unquestionably. For example, the legal responsibility of a judge or an officer of state security agencies may follow due to non-compliance with moral standards. According to Article 19.1 of Federal Law No. 57-FZ of May 27, 1996 "On State Protection", if the officers of the state securities regardless of their being on duty or not show any misconduct (inaction), which violates the Federal Law and (or) the code of ethics or code of on-duty behaviour for the officers of state security agencies, this may present grounds for dismissal from service or work in agency of the state security. Thus, the legal responsibility of officers of state security agencies comes for non-compliance not only with law, but also with ethical standards. In addition, technical regulations are often included in the provisions of Russian legislation, implying that there is certain convergence between different, sometimes heterogeneous regulators.

In addition to the convergence of social regulators there is a completely different feature of modular regulation, which is its vector orientation aimed at achieving a specific task with a high probability of free choice of behavioural pattern. At the same time, the main requirement must be met: it is necessary to achieve the set goals in the most productive way. In the process of making a final decision modular regulation creates conditions for ensuring the selection of the most effective social, technical or individual norm within a given vector of 
development. For example, in accordance with Part 2 of Article 10 of the Convention on $\mathrm{Hu}-$ man Rights and Biomedicine, everyone has the right to receive information about their health. However, the legal literature discusses the issue of the human right not to receive information ${ }^{3}$ about the possibility of an incurable disease if it is impossible to prevent its onset. I suppose that in each specific situation, there shall be the choice between the right of a person to receive whole information or their right not to receive negative information.

The choice of social norm is determined by a combination of factors that are caused by family characteristics, social status, and individual traits of the person tested. It is a kind of spontaneous regulator when this method is a one-off event used to solve a problem. It may be used as a part of modular regulation since it is sometimes not possible to provide for all the circumstances in the law. The orientation of modular regulation is conditioned by specific principles and goals to achieve them. In some areas of use of this type of regulation, there may be a list of prohibitions that limit modular development, and that is the measure to guarantee the principle of legality.

These main features of the proposed model of public relations regulation do not mean denying its other specifics.

Modular regulation should not be replaced by legal regulation as it should be used only to protect priority values. Here are the criteria for selection of modular regulation:

1. Maximum public danger due to violation of the specified parameters of the development of certain public relations.

2. A high degree of self-regulation in a certain sphere of public relations, the existence of specific patterns in it, which are sometimes difficult to subject to clearly defined legal regulation.

These criteria are to be met by genomic and other scientific research, since their consequences are now and then difficult to predict, and therefore the potential danger to humanity and society has the highest degree. There is

\footnotetext{
3 Cf.: Lipkin S.M., Luama, J. (2018). The Time for Genom. How Genetic Technologies Change the World and What it Means for us. Moscow, p. 36.
}

obvious existence of peculiar patterns and features in the field of scientific research. For example, information about one person's genome contains similar information about his family members. ${ }^{4}$ This applies to the peculiarities of genomic research and once again demonstrates the need for a different model of regulation than the legal one, which is substantiated by this article. Thus, modular regulation shall concern genomic research in particular.

First of all, let us consider the proposed structure of modular regulation (subjects, their rights, duties and responsibilities) and apply it to genomic and other scientific research.

Subjects of modular regulation have minimal differences from the analogues of legal regulation since they must also be endowed with civil and legal capacity. The only peculiarity of these subjects is the presence of special professional capacity, which allows to give qualified assessment of the whole range of circumstances when choosing a code of conduct.

Liabilities in the structure of modular regulation are largely determined by moral requirements, which can be either written (code of ethics) or unwritten. Hence the necessity to provide the rights of the aforementioned subjects to make a mistake. Otherwise, the lack of modularly provided risk in the process of choosing a specific research method will hamper further positive development of specific social relations. Medical law, for instance establishes a rigid framework for the conduct of doctors. Accordingly, being aware of a risky operation, a doctor will refuse to carry it out. Providing the right to make a mistake, modular regulation would enable a researcher to choose a risky version of professional activity and thereby save a patient's life in some situations.

Along with the right to make mistakes, another feature of the modular regulation of subjects' rights is the possibility of independent choice of a specific social or other norm. It is impossible to exclude a situation in which an applied moral or religious norm will not meet legal requirements. Such behaviour is

\footnotetext{
4 Cf: Kubitovich, S.N. (2017). DNK kak nositel' informatsii neogranichennogo kruga lits [DNA as information carrier for unlimited number of individuals]. In Vestnik ekonomicheskoi bezopasnosti [Bulletin of economic security], 4, 186.
} 
currently recognised as illegal with all the ensuing negative consequences. For instance, when in case of persistent negative symptoms, it is recommended to turn off the life-support machine, the termination of a patient's life does not correspond to moral values. However, there are examples of regaining consciousness after a long stay in such state ${ }^{5}$. It should be noted that with the legislative consolidation of modular regulation, legal liability for legal norms violation will not always be mandatory. Accordingly, it is possible to apply a moral norm about the priority of the value of a patient's life, even if it does not comply with the law. It is only important to comply with a given vector of modular regulation, which may mean the priority of a patient's interests. At the same time, Russian legislation, which establishes the status of the modular regulation participants, as well as possibilities and the limits of discretion of their action or inaction, should be recognised as a source of vector orientation.

Liability in the process of modular regulation should be accompanied by an expert testimony, which task is to determine the fact of exceeding the permissible limit of risk or apply the rule of the right to make mistakes.

Let us turn to the consideration of modular regulation of genomic research. Convergence of regulators as a feature of modular regulation is largely manifested in the process of intertwining morality and law. In this context, let us consider moral criteria in the legal regulation of genomic research. It is evident that without effective ethical control over the conduct of genetic research, scientific achievements can cause irreversible consequences both for a test subject and for the humanity as a whole. Intervention in the human genome, which can lead to the creation of a group of special people with desired properties, is especially dangerous, since it means a potential threat to the human species.

In these cases, not only an expert opinion, but adoption of the most objective decision on the ethical sufficiency or insufficiency

\footnotetext{
5 Ref.: Romanovskaya, O.V., Ryzhkova, A.A. (2019). Constitutional Legal Personality of Citizens in The Development of Biomedical Technologies. M., Prospect, 99.
}

of the possibility of conducting genomic research, and determining the optimal balance of the expected positive and negative consequences from this kind of genomic research are essential.

As noted earlier, in the process of scientific research which causes a change in the human genome, it is necessary to prevent the possibility of the most dangerous and negative consequences. Gene therapy can be carried out in three main ways: replacing a defective gene with a healthy one, repairing a faulty gene, and introducing a new gene to fight a disease. Any of the above methods is aimed at achieving the main goal - correct human genetics to fight a specific disease. Along with that, the danger of such genomic procedures is so high that legal regulators should strictly prevent negative consequences of such research. At the same time, it is vitally necessary and important to minimise the risks of harming human health and, especially, human life. Meanwhile, modular regulation should be used in such genetic studies as more efficient. In the process of changing the human genome, it is necessary to conduct ethics review to objectively assess the moral component of the possible consequences of conducting gene therapy. However, tight control over genomic research can sometimes hinder scientific advances, which can improve the health of specific people.

In the context of the topic of the present study, let us consider the problem of gene modification in more detail due to its ambiguity. In accordance with Article 13 of the Convention for the Protection of Human Rights and Dignity of the Human Being with regard to the Application of Biology and Medicine adopted in Oviedo on April 4, 1997, "an intervention seeking to modify the human genome may only be undertaken for preventive, diagnostic or therapeutic purposes and only if its aim is not to introduce any modification in the genome of any descendants." Particular attention should be paid to the fact that according to international standards, only somatic cells but not hereditary ones are subject to corrections. This provision regarding the absolute prohibition on the human hereditary gene modification seems quite controversial. 
Everyone has the right to life, which is provided for both by international acts and the Constitution of the Russian Federation (part 1, Article 20). The right to life will be significantly limited in case of refusal to modify a person's hereditary gene, provided that other methods of treatment will lead to a patient's death. It is obvious that changing the hereditary gene means correcting the genome of subsequent generations of a given patient who cannot agree to such therapy. From the position of a patient's children, their rights can also be violated if their parents' gene is modified. There is an ethical issue about the comparability of a patient and his/her descendant's rights. It is necessary to control the conduct of this kind of research and find the optimal balance of moral values. It seems that first of all, it is reasonable to correct the hereditary gene if there is no other medical way to save a patient's life, since in case of a patient's death, this test subject will not be able to have children. However, this kind of descendants' genome modification can lead to both positive and negative changes. Hence, it is necessary to develop regulatory solidarity of values when a doctor makes a decision, and a patient's position should be of crucial significance. It should be a patient who, along with a researcher, takes moral responsibility for his/ her future children.

Within the new model, it is important to consider the application limits for the legal regulators that do not coincide with the moral and other norms which may be more efficient in certain situations.

In every particular case, it necessary to apply the value regulator to achieve the set objective in a more efficient way, based on the optimal balance of negative and positive consequences. At the same time, it is required to fix and employ the minimum harm principle with the risks of modifying the inherited human genome and the possible consequences in mind. The methods listed above are typical for modular regulation, applicable in the genome research that allow for a freedom of choosing a certain standard of behaviour.

It is also essential to employ the regulatory solidarity as a modular regulation component of the genetic testing process, which is under- stood as testing a person for certain parameters of his/her genetic system. The objective of such study is to collect information on the disposition of the person to certain diseases. The purposes of the moral, religious and legal regulators are different. The task of the legal regulations is to determine the procedures and the moral regulation applicability limits, and their role is predetermined by the need for protecting the present moral values. The religious standards may also serve as a deterrent against the modification of the human genome. For this reason, we may speak of the modular regulation of the genome research, where all the subjects stick to the model of behaviour they have selected. Genetic testing should be differentiated by the method of using the data collected in the course of testing (positive or discriminative).

The positive method is intended to correct human behaviour in order to mitigate a risk of a disease. For example, based on the positive phenylketonuria test results, a pregnant woman may be recommended a special diet to reduce the risk for the embryo. In the future, the baby may live normal life without keeping to a diet. Such tests are intended to achieve a positive result. However, sometimes the negative side effects of such tests are impossible to forecast. For this reason, the genome research subject should select a pattern of behaviour on his own. The regulatory potential of morals in such tests appears to dominate over other norms. In the future, the use of the experimentally suggested modular regulation model in the genome testing may be discussed as well.

In case of the second mentioned method, the data may be used to discriminate a person, which contradicts Article 30 of the Constitution of the Russian Federation. For example, some medical information becomes available to employer, and based on this information the latter rejects the candidates with a risk of developing a particular disease. Therefore, the employer is rejecting a person with a detected abnormal gene, even though the disposition to the disease does not necessarily manifest itself. For this reason, the interests of the third parties and the patient need to be balanced. To achieve it, the value-based method should be used to solve the problem. 
Similar discrimination is typical for the insurance companies who may decline signing an insurance agreement with a tested person. To combat all kinds of discrimination, the genome information security system needs to be improved and the liability for disclosure of such information should be made inevitable. It is recommended to refer to the international standards. Thus, according to the Universal Declaration of the Human Genome and Human Rights (adopted on November 11, 1997 by the General Conference of the United Nations Educational Scientific and Cultural Organization), genome is defined as the heritage of humanity. The said declaration envisages the confidentiality of genome information and prohibits any forms of discrimination based on genetic characteristics.

At the same time, the right of an individual or organisation for receiving the required genome testing information needs to be ensured. I am convinced that for this purpose it is rational to foresee exceptional cases of prohibition against presentation of the information, if it can cause moral or material damage to the tested person. For example, to protect the public and national interests, a closed list of grounds for providing the genome test results to the employers should be legally adopted. It is important to prevent harm and to avoid disclosure of the confidential genome test information, when the health risk is minimal, but the rights and freedoms of a person may be infringed. Based on this, it is reasonable to apply a system of interconnected legal, moral and other regulators based on the solidarity principle, which is the essence of modular regulation.

\section{Conclusion}

In case of collision norms, the suggested modular regulation approach determines the criteria for selecting a particular regulator based on the convergence of the public and technical norms. Thus, in some situations it is required, first of all, to ensure the enforcement of the moral norms in the genome testing process. For example, it is reasonable to apply the ethical standards when making a decision whether to save a patient's life by correcting the inherited genome or to prohibit such a modification.

The modular regulation model has the following distinctive features:

- convergence of various norms for the achievement of the set objective of making an effect on the public relations;

- vector focus to the achievement of given goals;

- regulatory solidarity of the values as a regulator selection criterion;

- wide variety of legal behaviour of the person subject to modular regulation;

- additional mechanism of prosecuting people subject to modular regulation, including a compulsory independent expert evaluation of the committed deed (action or omission).

\section{References}

Ajunwa, I. (2014). Genetic testing meets Big data: Tort and Contract Law issues. In Ohio, State Law Journal, 75: 6, 1231.

Kubitovich, S.N. (2017). DNK kak nositel' informatsii neogranichennogo kruga lits [DNA as a Carrier of Information Belonging to an Unlimited Range of Persons]. In Vestnik ekonomicheskoi bezopasnosti [Economic Security Newsletter], 4, 184-188.

Lipkin, S.M., Luoma, J. (2018). Vremia genoma. Kak geneticheskie tekhnologii meniaiut nash mir $i$ chto eto znachit dlia nas [Age of Genomes: Tales from the Front Lines of Genetic Medicine]. Moscow. 298 p.

Romanovskaia, O.V., Ryzhkova, A.A. (2019). Konstitutsionnaia pravosub'ektnost' grazhdan v usloviiakh razvitiia biomeditsinskikh tekhnologiy [Constitutional Legal Capacity and Competence of Citizens in the Conditions of Developing Biomedical Technologies]. Moscow: Prospect, 144 p.

Khabrieva, T.Ia. (2018). Pravo pered vyzovami tsifrovoi real'nosti [Law Facing the Digital Reality Challenges], 9, 5-16. 


\title{
Современная модель регулирования геномных и иных научных исследований
}

\section{Н.М. Колосова}

Институт законодательства и сравнительного правоведения при Правительстве Российской Федеращии Российская Федерация, Москва

\begin{abstract}
Аннотация. Основной целью настоящего исследования является разработка качественно новой модели модульного регулирования общественных отношений, что позволит преодолеть стереотипы и недостатки правового регулирования.

Модель модульного регулирования характеризуется конвергенцией всех регуляторов, векторным направлением воздействия на общественные отношения и другими особенностями. В условиях противоречивости социальных регуляторов предлагаемая модель модульного воздействия на общественные отношения предоставляет возможность каждому выбирать наиболее эффективную норму.

Модульное регулирование, не заменяя правовое, следует использовать лишь в некоторых областях общественных отношений. Соответственно, критериями правомерности применения модульного регулирования признаются: очевидность наступления максимальных общественно опасных последствий в случае применения ошибочной нормы социального регулирования и высокая степень саморегулирования конкретной сферы общественных отношений, наличие в ней специфических закономерностей.

C учетом названных критериев модульное регулирование целесообразно использовать в геномных и иных научных исследованиях, что и является предметом настоящей статьи.
\end{abstract}

Ключевые слова: геном, статус исследователей, правовое регулирование, социальные регуляторы, модульное регулирование, право на ошибку, модификация гена, запрет дискриминации, геномное тестирование.

Работа была выполнена в рамках научного проекта РФФИ № 18-29-14009.

Научная специальность: 12.00.00 - юридические науки. 